\title{
Ritual complexity in a past community revealed by ancient DNA analysis of pre-colonial terracotta items from Northern Ghana
}

DOI:

10.1016/j.jas.2017.01.005

\section{Document Version}

Accepted author manuscript

Link to publication record in Manchester Research Explorer

Citation for published version (APA):

Robinson, H., Insoll, T., Kankpeyeng, B. W., Brown, K., \& Brown, T. (2017). Ritual complexity in a past community revealed by ancient DNA analysis of pre-colonial terracotta items from Northern Ghana. Journal of Archaeological Science, 79, 10-18. [2017.01.005]. https://doi.org/10.1016/j.jas.2017.01.005

\section{Published in:}

Journal of Archaeological Science

\section{Citing this paper}

Please note that where the full-text provided on Manchester Research Explorer is the Author Accepted Manuscript or Proof version this may differ from the final Published version. If citing, it is advised that you check and use the publisher's definitive version.

\section{General rights}

Copyright and moral rights for the publications made accessible in the Research Explorer are retained by the authors and/or other copyright owners and it is a condition of accessing publications that users recognise and abide by the legal requirements associated with these rights.

\section{Takedown policy}

If you believe that this document breaches copyright please refer to the University of Manchester's Takedown Procedures [http://man.ac.uk/04Y6Bo] or contact uml.scholarlycommunications@manchester.ac.uk providing relevant details, so we can investigate your claim.

\section{OPEN ACCESS}


1 Ritual complexity in a past community revealed by ancient DNA analysis

2 of pre-colonial terracotta items from Northern Ghana

4 Heather A. Robinson ${ }^{a,}$ Timothy Insoll ${ }^{\mathrm{b}, 1}$, Benjamin W. Kankpeyeng ${ }^{\mathrm{c}}$, Keri A. Brown ${ }^{\mathrm{a}}$, 5 and Terence A. Brown ${ }^{\mathrm{a},{ }^{*}}$

6

$7 \quad{ }^{a}$ Manchester Institute of Biotechnology, University of Manchester, Manchester M1 7DN, UK

$8{ }^{\mathrm{b}}$ Department of Archaeology, University of Manchester, Manchester M13 9PL, UK

$9{ }^{\mathrm{C}}$ Department of Archaeology and Heritage Studies, University of Ghana, P.O. Box LG 25,

10 Legon, Accra, Ghana

$12{ }^{1}$ Present address: Institute of Arab and Islamic Studies, University of Exeter, Exeter EX4 13 4ND, UK

$15{ }^{*}$ Corresponding author: Terry Brown, Manchester Institute of Biotechnology, University of

16 Manchester, Manchester M1 7DN, UK; Tel. 0044161306 4173; Email

17 terry.brown@manchester.ac.uk 


\section{Abstract}

20 The pre-colonial $6^{\text {th }}-14^{\text {th }}$ century terracotta forms of Koma Land, Northern Ghana, contain

21 cavities which may have been intended to hold liquids. These have been linked to traditional

22 African libation, but the specific nature of their contents is unclear. We used generic

23 polymerase chain reactions that would amplify DNA from a range of plant and fungal

24 species in order to identify remains of libations applied to fourteen terracotta items. We

25 anticipated difficulties in distinguishing genuine ancient DNA sequences from those resulting

26 from contaminating material, and therefore also carried out a series of control experiments

27 to assess the extent to which the samples had become contaminated with exogenous DNA

28 during burial, excavation and downstream analysis. Taking account of the results of the

29 control experiments, as well as the difficulties in assigning matches between ancient DNA

30 sequences and database entries, we provide evidence for the use of three different types of

31 plant - plantain/banana, pine and grasses - in libations associated with the terracotta items.

32 We also identified DNA from Coniochaeta yeast within the mouth cavity of one figurine,

33 suggesting that this structure was burnt prior to deposition.

35 Keywords: Africa, ancient DNA, Koma Land, libations, residue analysis, terracotta

\section{Introduction}

The striking terracottas from Koma Land, Northern Ghana, are a compelling record of

39 a $6^{\text {th }}-14^{\text {th }}$ century $A D$ community for which there is no written history or oral tradition

40 (Kröger, 1988). These anthropomorphic, zoomorphic and conical pottery items have drawn

41 considerable attention since anthropological studies and excavation of four mounds in the

42 region in the 1980s (Anquandah, 1987, 1998, 2003; Kröger, 1988), and the excavation of 
43 two further mounds in 2007-2011 (Kankpeyeng and Nkumbaan, 2008, 2009; Kröger and

44 Saibu, 2010; Kankpeyeng et al., 2011, 2013; Insoll et al., 2012, 2013).

Koma Land, in Northern Ghana, covers an area of approximately $100 \mathrm{~km}^{2}$

46 (Anquandah, 1998; Kankpeyeng et al., 2013) and features hundreds of mounds 4-35 m in

47 diameter, with a prominent mound cluster in the village of Yikpabongo. Some of the mounds

48 contain human remains (Anquandah, 1987), and it has been proposed that others

49 functioned for medicinal rituals or shrine worship (Kankpeyeng et al., 2011), perhaps as

50 places where ritually powerful materials, including the figurines, were deposited (Insoll et al.,

51 2012). The mounds were initially dated by thermoluminescence techniques to the $15^{\text {th }}-17^{\text {th }}$

52 centuries $A D$, although this chronology was subsequently extended to c.1200-1800 AD

53 (Anquandah, 1998).

An early anthropological survey of Yikpabongo and nearby villages equated the

locally spoken Mampruli language with the modern Koma language Konni, and concluded

that the society which produced the pottery items was continuous with the modern

population (Rattray, 1932). However, a subsequent survey recognized Konni as having

58 developed separately (Naden, 1986), and it is now widely accepted that the modern Koma

59 population migrated to this region, most likely arriving after 1880 (Kröger and Saibu, 2010).

60 Local oral traditions recount the discovery of ruins at the site, for which it was named

61 Yipkabongo ('forest ruins') (Dagan, 1989). It is suggested that the earlier pottery-producing

62 society may have abandoned their location due to pressures introduced by disease, famine

63 or the slave trade (Insoll et al., 2012, Kankpeyeng et al., 2013). This community is thought to

64 have occupied Yikpabongo between the $6^{\text {th }} / 7^{\text {th }}$ and $13^{\text {th }} / 14^{\text {th }}$ centuries AD (Kankpeyeng and

65 Nkumbaan, 2008, 2009; Kankpeyeng et al., 2011, 2013).

Many of the terracotta structures recovered from the mounds feature cavities up to 20

$67 \mathrm{~mm}$ in depth, as visualized by tube current modulation computer tomography (Insoll et al., 
68 2012, in press). In figurines, these cavities typically originate from the top of the head, ear,

69 nostril or mouth, and in cones the cavities extend downwards from the bowl. It has been

70 suggested that these cavities were reservoirs for libation (Insoll et al., 2012), the liquid

71 ceremonial offerings that can form a component of indigenous African religious practice

72 (Kilson, 1969; Mbiti, 1990; Essien 2014; Essel, 2014).

73 Pre-colonial West African libation is documented as having been offered with palm

74 wine (Baum 1999; Essel, 2014) and cola nut infusions (Kröger and Saibu, 2010), sorghum

75 or millet beer (Mbiti, 1990; Mulemi, 2004; Kröger and Saibu, 2010), water (Mbiti, 1990;

76 Baum, 1999; Kröger and Saibu, 2010; Essel, 2014), and in some instances, milk (Mbiti,

77 1990) or animal blood (Baum, 1999). The present Yikpabongo population cultivates pearl

78 millet, sorghum, African rice, yam and cassava (Kröger and Saibu, 2010), all of which can

79 be fermented (Jespersson, 2003; Mulemi, 2004; Mukisa et al., 2012; Lentz, 2013).

80 Additionally, bark/leaf infusions or pastes of 'magic' and medicinal plants (Myren, 2011; van

81 Andel et al., 2012) may have been applied to the items, given the suggested disease and

82 scapegoat themes in some of the figurine designs (Kankpeyeng et al., 2011; Insoll, 2015).

83 Analysis of ancient DNA (aDNA) from high temperature environments is usually

84 considered inadvisable (Murray et al., 2012; Campana et al., 2013), as heat accelerates

85 DNA hydrolysis and oxidation, reducing the likelihood of DNA sequence recovery (Pääbo

86 and Wilson, 1991; Burger et al., 1999; Krings et al., 1999; Reed et al., 2003; Willerslev and

87 Cooper, 2005; Lorenzen and Willerslev, 2010). Ancient DNA sequences have only

88 infrequently been recovered from warmer latitudes, typically from sites with cool

89 microclimates (Poinar et al., 2003; Gutiérrez-García et al., 2014), such as caves, which were

90 the source of the first ancient African human genome (Gallego Llorente et al., 2015). One

91 notable exception is the recovery of aDNA from $17^{\text {th }}$ century human remains from the

92 tropical Caribbean island of St. Martin (Schroeder et al., 2015). In North Africa, DNA has 
93 been shown to degrade to fragments $<100 \mathrm{bp}$ in length within 2000 years (Marota et al.,

94 2002; Hekkala et al., 2011; Khairat et al., 2013). However, only a third of Africa shares the

95 'hot desert' climate of the North (Kottek et al., 2006), and aDNA sequences up to $160 \mathrm{bp}$

96 have successfully been recovered from 2000-year-old desert cattle bones from Mali in West

97 Africa and Eritrea in the East (Edwards et al., 2004; Ascunce et al., 2007). The possible

98 contribution of aDNA studies in Sub-Saharan and central temperate and sub-tropical Africa

99 should therefore not be overlooked, especially in view of the archaeological richness of

100 these regions (e.g. Mclntosh, 1994, 2005; Yellen, 1998; Insoll, 2003; Stahl, 2004).

$101 \quad$ Non-destructive, forensic-inspired swab recovery methods can efficiently recover

102 aDNA from pottery, enabling systematic studies of large pottery assemblages without the

103 typical risks associated with sampling delicate artefacts (Foley et al., 2012). Here we report

104 the use of these methods to assess the usage of various terracotta items excavated in

105 Koma Land.

106

107 2. Materials and methods

$108 \quad 2.1$ Terracotta items

109 Samples were taken from nine terracotta figurines, two cones and three circular

110 disc/horn stoppers from mound YK07 (Kankpeyeng and Nkumbaan, 2008, 2009) and

111 mound YK10-3/YK11 (Kankpeyeng et al., 2011, 2013; Insoll et al., 2012), both in

112 Yikpabongo village, Koma Land (Fig. 1, Fig.2, Table 1). The items collectively span the five

113 Koma Land pottery forms (Kröger, 1988): cones with heads (category I), anthropomorphic

114 figures (II), Janiform figures, (III) animal forms (IV), and other uninterpreted forms (V). These

115 items were excavated over four seasons (Kankpeyeng and Nkumbaan, 2009; Insoll et al.,

116 2012), including two seasons during which excavators wore gloves and implemented

117 packing procedures in anticipation of downstream aDNA analysis (Insoll et al., 2012). 
118 Thermal age estimates (Smith et al., 2003) for the excavation series ranged from 18,567-

$11928,92910^{\circ} \mathrm{C}$ thermal years, with predicted mean fragment lengths of $13-19 \mathrm{bp}$, based on

120 the degradation pattern of bone aDNA (Table 2), placing the terracotta items close to the

121 likely threshold for aDNA recovery. Samples were taken with permission of the Ghana

122 National Museum, Accra.

2.2 Ancient DNA authentication regime

Sampling was carried out under clean conditions at the Manchester Museum on work

126 surfaces covered with two layers of aluminium foil. Personnel wore protective clothing

127 including forensic suits, face masks, hair nets, goggles and two pairs of sterile gloves at all

128 times, and all utensils and equipment were treated with DNA-Away (Thermo Scientific)

129 before and after use.

Ancient DNA analyses were performed in the aDNA laboratories of the University of

131 Manchester in a suite of independent, physically isolated laboratories, each with an

132 ultrafiltered air supply maintaining positive displacement pressure and a managed access

133 system. All surfaces within the laboratories were periodically sterilized by UV irradiation and 134 cleaned with $5 \%$ bleach and $70 \%$ ethanol, and all utensils and equipment were treated with 135 DNA-Away before and after use. Plasticware such as test tubes were UV irradiated (254 $136 \mathrm{~nm}, 120,000 \mu \mathrm{J} \mathrm{cm}{ }^{-2}$ for $2 \times 5 \mathrm{~min}$, with $180^{\circ}$ rotation between the two exposures) before 137 use. Aqueous solutions were similarly irradiated for 15 min. Personnel wore protective 138 clothing as described above at all times. DNA extractions were carried out in a Class II 139 biological safety cabinet in one laboratory within the facility, and PCRs were set up in a 140 laminar flow cabinet in a second, physically-isolated laboratory. All DNA extractions were 141 accompanied by at least two sample blanks (normal extraction but without sample), and 142 every set of eight PCRs was accompanied by at least one PCR blank (set up with water 
143 rather than DNA extract). A positive PCR (i.e. product of correct size and meaningful

144 sequence) was only considered authentic after replication with a second PCR of the same 145 extract.

\subsection{Sampling and DNA analyses}

Samples were taken from various cavities and surfaces from the terracotta items.

149 Following removal of soil with a sterile pick, each cavity was sampled with a sterile rayon 150 swab soaked in Tween $80+$ lecithin buffered to $\mathrm{pH} 7.4$ with sodium thioglycollate (Scientific 151 Laboratory Supplies) or, for smaller cavities, with sterile glass wool swabs prepared in the 152 aDNA laboratory, dipped in lysis buffer A (Promega Wizard Magnetic DNA Purification 153 System for Food) at the point of sampling. Tubes of lysis buffer A were also opened on the 154 workbench prior to the sampling of each item to provide the sample blanks.

DNA was extracted from each sample and from associated soil (Promega Wizard

156 Magnetic DNA Purification System for Food), eluted in a final volume of $100 \mu$, and

157 quantified (Thermo Fisher Scientific Quant-IT DNA Assay Kit and Qubit 2.0 Fluorometer).

158 The significance of possible correlations between the DNA concentrations of extracts and 159 variables including excavation mound, year and sample type (cavity, external surface or soil) 160 was assessed using a linear model, simplified following Crawley (2005), run in R v.3.0.1 (R 161 Development Core Team, 2009).

PCRs were carried out as described by Speirs et al. (2011) using the primers shown

163 in Table 3, using AmpliTaq Gold DNA Polymerase (Thermo Fisher Scientific). To avoid PCR 164 inhibition from residual soil contaminants, extracts were diluted and the equivalent of $0.015-$ $1650.150 \mu \mathrm{l}$ of the undiluted extract used per $30 \mu \mathrm{l} \mathrm{PCR}$, the amount determined by optimization 166 experiments. Cycling parameters were: $10 \mathrm{~min}$ at $95^{\circ} \mathrm{C} ; 40-50$ cycles of $45 \mathrm{~s}$ at $94^{\circ} \mathrm{C}, 1 \mathrm{~min}$ 167 at the annealing temperature, $1 \mathrm{~min} 20 \mathrm{~s}$ at $72^{\circ} \mathrm{C} ; 7 \mathrm{~min}$ at $72^{\circ} \mathrm{C}$. $\mathrm{PCR}$ products were 
168 purified from gels (QIAGEN MinElute PCR Purification Kit) and cloned (Thermo Fisher

169 Scientific CloneJET PCR Cloning Kit) in Escherichia coli XL1-Blue (Agilent). Colony PCR

170 was performed in $20 \mu \mathrm{l}$ reactions comprising $1 \times$ Taq buffer (New England Biolabs), $200 \mathrm{nM}$

171 each primer, 200 mM dNTPs and 0.625 units Taq DNA polymerase (New England Biolabs),

172 with cycling at: $95^{\circ} \mathrm{C}$ for $3 \mathrm{~min} ; 30$ cycles of $30 \mathrm{~s}$ at $94^{\circ} \mathrm{C}, 30 \mathrm{~s}$ at $60^{\circ} \mathrm{C}, 1 \mathrm{~min}$ at $72^{\circ} \mathrm{C} ; 10$

$173 \min$ at $72^{\circ} \mathrm{C}$. Single-stranded DNA was digested (GE Healthcare Illustra ExoProStar) and

174 the PCR products sequenced (ABi PRISM BigDye Terminator protocol).

175 Amplicons from the original DNA extracts were also sequenced on the GS Junior 454

176 (Roche) platform after multiplex library preparation using the GS FLX Rapid Library MID

177 Adaptors Kit and Titanium emPCR kit, with modifications to optimize short read recovery as

178 described by Penney et al. (2013). All the test reads passed the standard quality controls

179 and control reads were of good quality. As the test read numbers were low, duplicates were

180 not removed prior to downstream processing. Sequences were manipulated in Geneious

181 v.8.0.3 (available from: http://www.geneious.com/), and aligned using Seaview v.4.5.3

182 (Galtier et al., 1996; Gouy et al., 2010). Sequences, excluding primer binding sites in the

183 case of PCR products, were compared with the NCBI database using BLASTn (Altschul et

184 al., 1990) using standard parameters (word size 11, DUST filter on, expect value 10,

185 match/mismatch score 2,-3, gap costs existence 5 extension 2). Sequence data and

186 barcodes are curated at the European Nucleotide Archive under project accession number

187 PRJEB11221 (Supplementary Table 2).

189 3. Results

$190 \quad 3.1$ DNA concentrations of extracts

191 The DNA concentrations of the extracts ranged from $<0.05-3.32 \mathrm{ng} \mathrm{\mu l}^{-1}$

192 (Supplementary Table 1). Using a basic linear model, correlations were tested between 
193 DNA concentration and excavation year, mound or sample type (cavity, external surface or

194 soil), including a potential interaction between excavation year and mound. The only

195 significant correlation was with sample type $(p=0.04)$, soil samples having a significantly

196 higher DNA concentration than the swab samples taken from cavities or external surfaces.

197 There was no statistical support for a correlation between the DNA concentration of the

198 extracts and excavation year $(P=0.35)$ or mound $(P=0.63)$.

\subsection{Assessment of modern contamination}

Sample blanks (tubes of buffer exposed during sampling of items) and PCR blanks

202 (set up with water instead of extract) occasionally gave single or multiple products of various

203 sizes. Cloning and sequencing indicated that in all but one case these products were primer204 dimers or non-specific bacterial amplicons. The single occasion on which an authentic PCR 205 product was obtained from a blank is described below.

As well as the sample and water blanks, the extent of exogenous DNA contamination

207 during burial, excavation and/or analysis of the terracotta items was assessed by four 208 different PCRs, carried out in duplicate with each of the DNA extracts. Two of these PCRs were designed to detect DNA from major crops grown in the vicinity of the mounds. The

210 ATPC primer pair (Table 3) targeted the vacuolar ATPase C gene of pearl millet

211 (Pennisetum glaucum), a staple regional food crop (Rao et al., 1985; Kröger and Saibu, 212 2010), and the RBSP primer pair (Gyulai et al., 2007) amplified part of the S15 ribosomal 213 protein gene of maize (Zea mays), a recently introduced species farmed nearby (Kröger and 214 Saibu, 2010). No extracts gave PCR products of the expected size with either the ATPC or 215 RBSP primer pairs, the only products obtained from these PCRs being shown by 216 sequencing to be either primer-dimers, non-specific bacterial amplicons, or short sequences 217 that could not be identified by BLASTn analysis. 
Two other PCRs were designed to test for contamination with mammalian and/or

219 human DNA. Four extracts gave products of the expected size with the human-specific

220 mitochondrial HVR1 primers (Table 3; Bouwman et al., 2008). Sequencing of these four

221 HVR1 PCR products, two of which originated from pottery disc stoppers (items YK07-2-85-1

222 and YK07-2-B5-1), one from soil removed from the mouth of the 'large head' (YK07-2-B5.1),

223 and one from the exterior of the 'human head wearing hat' (YK08-A9B9-L7), showed that

224 each contained human DNA. Sequencing placed these amplicons in the HV haplogroup,

225 which is uncommon in present-day Africa, suggesting that they derive from handling during

226 or after excavation. Eight extracts gave products of the expected size with the CYTB primer

227 pair (Table 3), which is designed to amplify part of the mitochondrial cytochrome b gene

228 from mammalian species (Irwin et al., 1991), but sequencing showed these either to be

229 bacterial in origin or unidentifiable.

$230 \quad$ No human DNA was detected from items excavated during seasons 2010-

23111 , indicating that the precautions used to prevent contamination in the field had been

232 effective. One sample blank gave an HVR1 product which matched the sequence of

233 individuals present when samples were taken, but this sequence was not obtained from any

234 of the test extracts.

2363.3 Identification of possible plant libation offerings

237 Two PCRs were carried out with primer pairs designed to amplify a variety of plant

238 species that might have been components of libation offerings. The RBCL PCR used

239 primers h1aE and h2aR (Poinar et al., 1998), which amplify part of the chloroplast gene for

240 the large subunit of ribulose-1,5-bisphosphate carboxylase, and the TRNL primer pair were

241 designed by us to amplify part of the chloroplast trnL (tRNA ${ }^{\text {Leu }}$ ) gene (Table 3). Both primer

242 pairs are generic to multiple land plants, and would be expected to amplify DNA from a 
243 range of species. With several extracts, these PCRs resulted in a mixture of products of

244 different lengths. For nine PCRs, two with the RBCL primer pair and seven with the TRNL

245 primers, the products included an amplicon of, or close to, the expected length (Table 4).

246 These amplicons were further examined by purification from the electrophoresis gel followed

247 by cloning and sequencing.

248 The TRNL PCRs from two samples, taken from the mouth cavity of the 'large head

249 form' YK-07-2-B5.1 and the nostril cavity of a 'combined human and animal head' YK11-

$250 \mathrm{H} 13 \mathrm{H} 14-113114$ gave products whose sequences closely matched members of the Musa

251 and Ensete genera, which include bananas and plantains (Supplementary Fig. 1). Ten

252 clones were obtained from the YK07-2-B5.1 PCR, five of which gave matches to the

253 sequence database. Three of these clones gave sequences that were an exact match to a 254 variety of Musa species and a single Ensete species, Ensete lasciocarpa. The two other

255 clones contains single mismatches to the same sequences. A single clone from the YK11-

$256 \mathrm{H} 13 \mathrm{H} 14-113114 \mathrm{PCR}$ gave a sequence with two polymorphisms to the various Musa

257 species and E. lasciocarpa. Additionally, an RBCL PCR of a sample from the exterior

258 surface adjacent to the mouth cavity of YK07-2-B5.1 gave a weak product of the correct

259 size, which was not replicated in the duplicate PCR. This product could not be cloned, but a 260 partial direct sequence matched the Order Zingiberales, which includes Musa and Ensete, 261 with the exception of a single indel.

262 The TRNL PCRs of samples taken from the nasal cavity of the 'combined human and 263 animal head' YK11-H13H14-113114, and the exterior of the 'large conical figure' YK07-2264 A4-1 yielded sequences whose closest matches were with members of the Order Pinales 265 (Supplementary Fig. 2). Seven clones from YK11-H13H14-113114 and five from YK07-2266 A4-1 gave sequences identical to those of various Pinus species, and when repeating the 
267 query excluding Pinus sequences, to Araucaria araucana (monkey puzzle). Multiple 268 mismatches were observed to all other database sequences.

A sample from the nostril of the 'seated female figure' $Y K 10-D 11-3$ gave RBCL

270 sequences which were close matches to database entries for various species of the

271 Poaceae (grasses). Four clones exactly matched a sequence conserved in the Triticum,

272 Hordeum, Elymus and Secale genera, which comprise widely cultivated cereals, as well as

273 other grass genera (Supplementary Fig. 3A). These sequences had no significant

274 similarities with millet or maize and so are unlikely to be modern environmental

275 contaminants. Three further clones from this PCR product differed by up to three bases,

276 which might indicate DNA damage. An exterior sample, also from the seated female figure,

277 gave a TRNL product that was an exact match to sequences in the Triticeae tribe and also

278 to Lolium perenne (rye grass). This sequence was replicated across nine clones

279 (Supplementary Fig. 3B).

280 Products of the expected size were also obtained after TRNL PCR of samples from

281 the left mouth cavity of the 'horse and rider' YK07-AB9-L7 and the exterior of the

282 'anencephalic head' YK07-2-A8-1, as well as from a soil sample from a cavity of the 'large

283 head' YK07-2-B5.1. After cloning and sequencing, these products gave no significant

284 matches with entries in the NCBI database (Table 4).

285

2863.4 Identification of environmental fungi

287 The RDNA primer pair (Table 3) was designed by us to amplify part of the large

288 subunit ribosomal RNA gene and adjacent internal transcribed spacer region from a range

289 of ascomycete fungi. This PCR was intended to test for the presence of yeasts such as

290 Saccharomyces cerevisiae, which might indicate that the libations included fermented

291 products. The PCR was successful with three extracts, from the mouth cavity of the "horse 
and rider' YK08-AB9-L7, the ear hole of the 'seated female figure' YK10-O11-3, and the

293 exterior of the 'large conical figure' YK07-2-A4-1. As only the product from YK07-2-A4-1C2

294 could be cloned, the products from YK08-AB9-L7 and YK10-011-3 were sequenced using 295 the GS Junior 454 platform (Supplementary Table 3). The sequences obtained for YK10296 O11-3 and YK07-2-A4-1C2 were predominantly primer artefacts, but those from YK08-AB9297 L7 fell into two groups, distinguished by a single-nucleotide difference. These sequences 298 were most closely matched with database entries for the yeasts Coniochaeta africana and 299 Coniochaeta gigantospora (Supplementary Fig. 4).

\section{Discussion}

We used generic PCRs that would amplify DNA from a range of plant and fungal species to identify remains of libations applied to terracotta items from Koma Land, dating 304 from the $9^{\text {th }}-14^{\text {th }}$ centuries $A D$. Thermal age estimates indicated that the items are close to the threshold for aDNA recovery, and we anticipated difficulties in distinguishing genuine aDNA sequences from those resulting from contaminating material. In order to assign an appropriate degree of confidence to our results, we therefore carried out a series of control experiments to assess the extent to which the terracotta items had become contaminated with exogenous DNA during burial, excavation and downstream analysis.

PCRs directed at pearl millet and maize, the two major agricultural crops grown in 311 present-day Koma Land, were negative, suggesting minimal contamination with surface 312 vegetation. Sporadic contamination with modern human DNA was detected for items 313 excavated prior to $2010-11$, the first season when precautions were taken to prevent 314 handling contamination. For this reason, we made no attempts to assess the use of human 315 products as libations. 
317 YK07-2-B5-1, YK07-2-C4-L2), which are believed to be repurposed from broken pots. Their 318 actual function is unknown, but they are unlikely to have served the same purposes as the 319 figurines with which they were co-excavated. These stoppers therefore act as negative 320 controls, and are more suitable for this purpose than the outer surfaces of the figurines, as 321 libations might have been poured over the latter as well as applied to cavities. None of these 322 stoppers yielded plant or fungal sequences similar to those that we obtained from some of 323 the figurines. Sample blanks (exposed during sampling of the items) and water blanks 324 (PCRs set up with water rather extract) yielded only sporadic products shown to be primer325 dimers or non-specific bacterial amplicons, except for one sample blank that gave a human 326 DNA sequence probably derived from one of the individuals present when samples were 327 taken. With zero evidence for environmental contamination, absence of 'interesting' 328 sequences from the discs, and only sporadic contamination with human DNA, we believe 329 that we are justified in drawing tentative conclusions from those plant and fungal sequences 330 that we detected in samples from the Koma Land figurines. Sequences obtained from generic PCRs must be interpreted with care when comparisons are made by BLASTn analysis. Although we targeted chloroplast sequences 333 that are well-studied in plants, the entries in the NCBI database are far from comprehensive 334 and are biased towards model species and ones with agricultural or economic importance. 335 Many species, especially from less studied ecosystems such as those of West Africa, are 336 under-represented in the database. BLASTn analysis reveals the closest matches to a query 337 sequence, and those matches might display sequence identity, but this does not constitute a 338 definite identification of the query sequence, as the possibility remains that the query 339 sequence derives from a species that is not present in the database. Interpretation of 340 BLASTn results becomes even less specific when the query has non-identity with the 
341 closest database match, especially with aDNA where non-identities might be genuine

342 differences between query and closest match, or might be due to miscoding lesions in the

343 query sequence, resulting from damage to the aDNA template.

344 The cavities of two items, the mouth cavity of the 'large head form' YK-07-2-B5.1 and

345 the nostril cavity of a 'combined human and animal head' YK11-H13H14-113114, which

346 were excavated during different years and from different mounds (Table 1), gave TRNL

347 sequences that matched a variety of Musal Ensete (banana and plantain) species. Item YK-

348 07-2-B5.1 also yielded an RBCL sequence which could be assigned to Order Zingiberales.

349 The Musa and Ensete genera, including bananas and plantains, are non-native to Ghana,

350 and little is known of their West African history (Stover and Simmonds, 1987; Blench, 2009).

351 Plantains have become a dietary staple in West Africa, which might indicate that they were

352 introduced into the region prior to bananas (Tezenas du Montcel et al., 1983; De Langhe,

353 2007). Phytolith studies have placed domesticated banana cultivars in Cameroon by 1000

354 BC (Lejju et al., 2006), suggesting a relatively early introduction of edible Asian cultivars via

355 Central Africa. Plantain and banana cultivars were not described in accounts of the staple

356 crops cultivated at the Koma Land site in 2010, nor do they appear to supplement the 357 current population's regular diet (Kröger and Saibu, 2010). Elsewhere in Sub-Saharan

358 Africa, plantains and bananas are boiled, pounded into fufu paste with cassava, or brewed

359 to produce beer and wine (Tezenas du Montcel et al., 1983; Shale et al., 2012). In the

360 samples that we studied, however, we detected only one fermenting yeast genus,

361 Coniochaeta, which primarily ferments rotting wood. We therefore have no evidence to

362 support the use of fermented MusalEnsete products, but cannot discount this possibility.

363 The two figurines from which we obtained these sequences have large, open mouths that

364 lack a rear cavity, in contrast to the cavities or closed mouths found on many other figures,

365 and could therefore have been designed to receive pastes rather than liquids. Solid 
366 substances are known to have been associated with figurine cavities produced by cultures 367 such as the Songye (Hersak, 2013), although in these cases the cavities tend to be located

368 in the abdomen and anus, cavity positions which are not represented on the Koma Land 369 figurines.

$370 \quad$ We obtained TRNL sequences matching various Pinus species and Araucaria 371 araucana (monkey puzzle) from the nasal cavity of the 'combined human and animal head' 372 YK11-H13H14-113114, and the exterior of the 'large conical figure' YK07-2-A4-1. These 373 items were recovered from different mounds during different years. Pines are farmed 374 primarily in Southern Ghana, and no stands are present proximal to the study site. Tree bark 375 is commonly boiled in traditional African medicinal rituals to produce infusions perceived to 376 have restorative powers (van Andel et al., 2012). Pinus halepensis, Pinus pinaea, Pinus 377 brutia and Pinus negra were all established in North Africa prior to the production of the 378 Koma Land figurines (Nicholson and Shaw, 2000), and it is possible that conifer needles, 379 cones or bark were traded from North Africa, as were cowry shells and beads (Anquandah, 380 1998; Insoll et al., 2012). The representation of a horse or camel on item YK08-AB9-L7 381 could suggest an interaction between the Koma Land population and outside groups 382 (Anquandah, 1998; Insoll et al., 2012).

We also obtained evidence of grass DNA from the 'seated female figure' YK10-D11-

384 3. The RBCL sequences gave an exact match with a wide range of grass genera, while the 385 TRNL sequence was specific to the Triticeae. Many of the sequence matches belong to 386 widely cultivated cereals, but not to maize and millet, indicating a possible ritual application 387 of grains as pastes or in infusions.

The final positive identification that we made was for Coniochaeta yeast DNA present 389 in the mouth cavity of the 'horse and rider' YK08-AB9-L7. These sequences were detected 390 only in the second of two samples taken from this cavity, and were not detected in soil 
391 removed from the cavity, suggesting that the cavity contained Coniochaeta yeasts when the

392 figurine was buried. Coniochaeta are early colonizers of post-fire sites, creating a

393 characteristic fungal bloom (Wicklow, 1973; Mahoney and LaFavre, 1981; Innes and

394 Blackford, 2003; Mighall et al., 2007). The figurine YK08-AB9-L7 was excavated from what

395 appears to be scorched earth (Kankpeyeng and Nkumbaan, 2009), although it was unclear

396 whether the figurine was burnt in situ or fortuitously positioned within the burnt area. The

397 presence of Coniochaeta within the mouth cavity suggests that the item was deliberately

398 burnt. The majority of the Koma Land figurines feature deliberate breaks or missing

399 elements consistent with deconsecration prior to burial (Insoll et al., 2012), and items such

400 as YK07-2-A4-1 also display scorch marks. Burning might therefore have been used as a

401 means of deactivating powerfully perceived spiritual objects, perhaps considered to be

402 invested with some form of personhood (Insoll et al., 2012).

403

404 5. Conclusion

405 Despite the Koma Land terracottas having thermal ages placing them at the limits of 406 aDNA analysis, and despite the problems inherent in interpretation of sequences obtained 407 with generic PCRs, we provide evidence for the use of three different types of plant 408 plantain/banana, pine and grasses - in libations associated with the figurines. We also 409 provide evidence for deliberate burning of one figurine. The use of multiple types of libations 410 using traded exotic commodities, and the practise of selective burning suggests that ritual 411 activities in pre-colonial Koma Land had a complexity that rivals that of current indigenous

412 African religious practices. Further contextual interpretation of our results will contribute to 413 future research on this understudied part of the world pottery record.

\section{Acknowledgements}


416 We thank The Ghana Museums and Monuments Board for sampling permissions,

417 Samantha Sportun of the conservation team at The Manchester Museum for assistance with

418 sampling, and Saviour Gidi of the University of Ghana for preparing Figure 1. We thank

419 Romy Müller and The University of Manchester Sequencing Facility for technical advice, and

420 all who continue to work towards the excavation, conservation and exhibition of the Koma

421 Land items. This work was funded by the first author.

422

423 References

424 Altschul, S.F., Gish, W., Miller, W., Myers, E.W., Lipman, D.J., 1990. Basic local alignment 425 search tool. J. Mol. Biol. 215, 403-410.

426 Anquandah, J.R., 1987 L'art du Komaland: une découverte récente au Ghana septentrional. $427 \quad$ A. Afrique Noire 62, 11-18.

428 Anquandah, J., 1998. Koma-Bulsa: its Art and Archaeology. Istituto italiano per l'Africa e 429 I'Oriente, Rome.

430 Anquandah, J., 2003. Les arts des Koma-Bulsa, in: Falgayrettes-Leveau, C., Owusu431 Sarpon, C. (Eds.), Ghana. Hier et Aujourd'hui. Musée Dapper, Paris, pp .135-149.

432 Ascunce, M.S., Kitchen, A., Schmidt, P.R., Miyamoto, M.M., Mulligan, C.J., 2007. An 433 unusual pattern of ancient mitochondrial DNA haplogroups in northern African cattle. 434 Zool. Stud. 46, 123-125.

435 Baum, R.M., 1999. Shrines of the Slave Trade: Diola Religion \& Society in Precolonial 436 Senegambia: Oxford University Press, Oxford.

437 Blench, R., 2009. Bananas and plantains in Africa: re-interpreting the linguistic evidence. 438 Ethnobot. Res. Appl. 7, 363-380. 
439 Bouwman, A.S., Brown, K.A., Prag, A.J.N.W., Brown, T.A., 2008. Kinship between burials 440 from Grave Circle B at Mycenae revealed by ancient DNA typing. J. Archaeol. Sci. 35, $441 \quad 2580-2584$.

442 Burger, J., Hummel, S., Hermann, B., Henke, W., 1999. DNA preservation: microsatellite$443 \quad$ DNA study on ancient skeletal remains. Electrophoresis 20, 1722-1728.

444 Campana, M.G., Bower, M.A., Crabtree, P.J., 2013. Ancient DNA for the archaeologist: the 445 future of African research. Afric. Archaeol. Rev. 30, 21-37.

446 Crawley, M.J., 2005. Statistics: an Introduction using R. Wiley-Blackwell, Chichester.

447 Dagan, E.A., 1989. Spirits Without Boundaries: Twenty-six Terracotta Single Heads from $448 \quad$ Komaland, Ghana. Galerie Amrad African Arts, Montreal.

449 De Langhe, E., 2007. The establishment of traditional plantain cultivation in the African 450 rainforest: a working hypothesis, in: Denham, T., Vrydaghs, L., Iriarte, J. (Eds.), 451 Rethinking Agriculture: Archaeological and Ethnoarchaeological Perspectives. Left Coast 452 Press, Walnut Creek, pp. 361-370.

453 Edwards, C.J., MacHugh, D.E., Dobney, K.M., Martin, L., Russell, N., Horwitz, L.K., 454 Mclntosh, S.K., MacDonald, K.C., Helmer, D., Tresset, A., Vigne, J-D., Bradley, D.G., 455 2004. Ancient DNA analysis of 101 cattle remains: limits and prospects. J. Archaeol. Sci. $456 \quad 31,695-710$.

457 Essel, O.Q., 2014. Libation art in art of Ghana: linking the unlinked. Int. J. Afr. Soc. Cult. $458 \quad$ Trad. 1, 39-49.

459 Essien, E.D., 2014. Toward an impirical inquiry of religious language in the interface of 460 libation rituals in West Africa: experience from Ibibio, Nigeria. Adv. Soc. Sci. Res. J. 1, $461 \quad 129-141$. 
462 Foley, B.P., Hansson, M.C., Kourkoumelis, D.P., Theodoulou, T.A., 2012. Aspects of 463 ancient Greek trade re-evaluated with amphora DNA evidence. J. Archaeol. Sci. 39, 389464398.

465 Gallego Llorente, M., Jones, E.R., Eriksson, A., Siska, V., Arthur, K.W., Arthur, J.W., Curtis, 466 M.C., Stock, J.T., Coltorti, M., Pieruccini, P., Stretton, S., Brock, F., Higham, T., Park, Y., 467 Hofreiter, M., Bradley, D.G., Bhak, J., Pinhasi, R., Manica, A., 2015. Ancient Ethiopian 468 genome reveals extensive Eurasian admixture in Eastern Africa. Science 350, 820-822. 469 Galtier, N., Gouy, M., Gautier, C., 1996. SEAVIEW and PHYLO_WIN, two graphic tools for 470 sequence alignment and molecular phylogeny. Comput. Applic. Biosci. 12, 543-548.

471 Gouy, M., Guindon, S., Gascuel, O., 2010. SeaView version 4: A multiplatform graphical 472 user interface for sequence alignment and phylogenetic tree building. Mol. Biol. Evol. 27, $473 \quad 221-224$.

474 Gutiérrez-García, T.A., Vázquez-Domínguez, E., Arroyo-Cabrales, J., Kuch, M., Enk, J., 475 King, C., Poinar, H.N., 2014. Ancient DNA and the tropics: a rodent's tale. Biol. Lett. 10, 47620140224.

477 Gyulai, G., Humphreys, M.O., Lagler, R., Szabó, Z., Tóth, Z., Bittsanszky, A., Gyulai, F., 478 Heszky, L.E., 2007. Seed remains of common millet from the $4^{\text {th }}$ (Mongolia) and $15^{\text {th }}$ 479 (Hungary) centuries: AFLP, SSR and mtDNA sequence recoveries. Seed Sci. Res. 16, $480 \quad 179-191$.

481 Hekkala, E., Shirley, M.H., Amato, G., Austin, J.D., Charter, S., Thorbjarnarson, J., Vliet, 482 K.A., Houck, M.L., Desalle, R., Blum, M.J., 2011. An ancient icon reveals new mysteries: 483 mummy DNA resurrects a cryptic species within the Nile crocodile. Molec. Ecol. 20, $484 \quad 4199-4215$.

485 Hersak, D. 2013. Beyond the naked eye. Crit. Interv. 7, 95-104. 
486 Innes, J.B., Blackford, J.J., 2003. The ecology of late Mesolithic woodland disturbances:

487 model testing with fungal spore assemblage data. J. Archaeol. Sci. 30, 185-194.

488 Insoll, T., 2003. The Archaeology of Islam in Sub-Saharan Africa. Cambridge University 489 Press, Cambridge.

490 Insoll, T., 2015. Material Explorations in African Archaeology. Oxford University Press, 491 Oxford

492 Insoll, T., Kankpeyeng, B.W., 2014. Reconstructing the archaeology of movement in 493 northern Ghana: insights into past ritual, posture, and performance, in: Ogundiran, A., 494 Saunders, P. (Eds.), Materialities of Ritual in the Black Atlantic. Indiana University Press, 495 Bloomington, pp. 28-46.

496 Insoll, T., Kankpeyeng, B.W., Nkumbaan, S.N., 2012. Fragmentary ancestors? Medicine, 497 bodies, and personhood in a Koma mound, northern Ghana, in: Rountree, K., Morris, C., 498 Peatfield, A.A.D. (Eds.), Archaeology of Spiritualities. Springer, New York, pp. 25-45. 499 Insoll, T., Kankpeyeng, B.W., Nkumbaan, S., Saako, M., 2013. Fragmentary Ancestors. 500 Figurines from Koma Land, Ghana. The Manchester Museum, Manchester.

501 Insoll, T., Kankpeyeng, B., Fraser, S., in press. Internal meanings: computed tomography 502 scanning of Koma figurines from Ghana. Afr. Arts

503 Irwin, D.M., Kocher, T.D., Wilson, A.C., 1991. Evolution of the cytochrome b gene of 504 mammals. J. Mol. Evol. 32, 128-144.

505 Jesperson, L., 2003. Occurrence and taxonomic characteristics of strains of predominant in 506 African indigenous fermented foods and beverages. FEMS Yeast. Res. 3, 191-200.

507 Kankpeyeng, B.W., Nkumbaan, S.N., 2008. Rethinking the stone circles of Komaland: a 508 preliminary report on the 2007/2008 fieldwork at Yikpabongo, Northern Region, Ghana, 509 in: Insoll, T. (Ed.), Current Archaeological Research in Ghana, Cambridge Monographs in 
$510 \quad$ African Archaeology 74, BAR International Series 1847, Archaeopress, Oxford, pp. 95-

$511 \quad 102$.

512 Kankpeyeng, B.W., Nkumbaan, S.N., 2009. Ancient shrines? new insights on the Koma

513 Land sites of Northern Ghana, in: Magnavita, S., Koté, L., Breunig, P., Idé, O.A. (Eds.),

514 Crossroads/Carrefour Sahel: Cultural and Technological Developments in First

515 Millennium BC/AD West Africa. Africa Magna Verlag, Frankfurt, pp. 193-202.

516 Kankpeyeng, B.W., Nkumbaan, S.N., Insoll, T., 2011. Indigenous cosmology, art forms and

517 past medicinal practices: towards an interpretation of ancient Koma Land sites in northern

518 Ghana. Anthropol. Med. 18, 205-216.

519 Kankpeyeng, B., Swanepoel, N., Insoll, T., Nkumbaan, S., Amartey, S., Saako, M., 2013.

520 Insights into past ritual practice at Yikpabongo, Northern Region, Ghana. Afr. Archaeol.

$521 \quad$ Rev. 30, 475-499.

522 Khairat, R., Ball, M., Chang, C.C., Bianucci, R., Nerlich, A.G., Trautmann, M., Ismail, S.,

523 Shanab, G.M., Karim, A.M., Gad, Y.Z., Pusch, C.M., 2013. First insights into the

524 metagenome of Egyptian mummies using next-generation sequencing. J. Appl. Genet.

$525 \quad 54,309-325$.

526 Kilson, M., 1969. Libation in Ga ritual. J. Relig. Afr. 2, 161-178.

527 Kottek, M., Grieser, J., Beck, C., Rudolf, B., Rubel, F., 2006. World map of the Köppen-

528 Geiger climate classification updated. Meteorol. Z. 15, 259-263.

529 Krings, M., Salem, A.E., Bauer, K., Geisert, H., Malek, A.K., Chaix, L., Simon, C., Welsby,

530 D., Di Rienzo, A., Utermann, G., Sajantila, A., Pääbo, S., Stoneking, M., 1999. mtDNA

531 analysis of Nile River Valley populations: a genetic corridor or a barrier to migration? Am.

$532 \quad$ J. Hum. Genet. 64, 1166-1176.

533 Kröger, F., 1988. Die terrakotta-funde des Koma-Gebietes (Nordghana). Paideuma 34, 129_ 534142. 
535 Kröger, F., Saibu, B.B. (Eds.), 2010. First Notes on Koma Culture: Life in a Remote Area of $536 \quad$ Northern Ghana. LIT Verlag, Münster.

537 Lejju, B.J., Robertshaw, P., Taylor, D., 2006. Africa's earliest bananas? J. Archaeol. Sci. 33, $538 \quad 102-113$.

539 Lentz, C., 2013. Alcohol consumption between community ritual and political economy: case 540 studies from Ecuador and Ghana, in Lentz, C. (Ed.), Changing Food Habits: Case Studies 541 from Africa, South America and Europe. Harwood Academic Publishers, New York, pp. $542 \quad 155-180$.

543 Lorenzen, E.D., Willerslev, E., 2010. King Tutankhamun's family and demise. J.A.M.A. 303, $544 \quad 2471-2475$.

545 Mahoney, D.P., LaFavre, J.S., 1981. Coniochaeta extramundana, with a synopsis of other $546 \quad$ Coniochaeta species. Mycologia 73, 931-952.

547 Marota, I., Basile, C., Ubaldi, M., Rollo, F., 2002. DNA decay rate in papyri and human 548 remains from Egyptian archaeological sites. Am. J. Phys. Anthropol. 117, 310-318. 549 Mbiti, J.S., 1990. African Religions and Philosophy, second ed. Heinemann, London. 550 Mclntosh, S.K., 1994. Changing perceptions of West Africa's past: archaeological research 551 since 1988. J. Archaeol. Res. 2, 165-198.

552 Mclntosh, S.K., 2005. Beyond Chiefdoms: Pathways to Complexity in Africa. Cambridge $553 \quad$ University Press, Cambridge.

554 Mighall, T.M., Timpany, S., Blackford, J.J., Innes, J.B., O'Brien, C.E., O'Brien, W., Harrison, 555 S., 2007. Vegetation change during the Mesolithic and Neolithic on the Mizen Peninsula, $556 \quad$ Co. Cork, south-west Ireland. Veget. Hist. Archaeobot. 17, 617-628.

557 Mukisa, I.M., Porcellato, D., Byaruhanga, Y.B., Muyanja, C.M., Rudi, K., Langsrud, T., 558 Narvhus, J.A., 2012. The dominant microbial community associated with fermentation of 
559 Obushera (sorghum and millet beverages) determined by culture-dependent and culture560 independent methods. Int. J. Food Microbiol. 160, 1-10.

561 Mulemi, B.A., 2004. Libation, in: Peek, P.M., Yankah, K. (Eds.), African Folklore: An

562 Encyclopedia, Routledge, London, pp. 423-429.

563 Murray, D.C., Pearson, S.G., Fullagar, R., Chase, B.M., Houston, J., Atchison, J., White, 564 N.E., Bellgard, M.I., Clarke, E., Macphail, M., Gilbert, M.T.P., Haile, J., Bunce, M., 2012. $565 \quad$ High-throughput sequencing of ancient plant and mammal DNA preserved in herbivore 566 middens. Quat. Sci. Rev. 58, 135-145.

567 Myren, B., 2011. Magic Plants in the South of Ghana. National Biodiversity Center, Leiden.

568 Naden, A.J., 1986. Première note sure le Konni. J. West. Afr. Lang. 16, 76-112.

569 Nicholson, P.T., Shaw, I., 2000. Ancient Egyptian Materials and Technology. Cambridge $570 \quad$ University Press, Cambridge.

571 Pääbo, S., Wilson, A.C., 1991. Miocene DNA sequences - a dream come true? Curr. Biol. 1, $572 \quad 45-46$.

573 Penney, D., Wadsworth, C., Fox, G., Kennedy, S.L., Preziosi, R.F., Brown, T.A., 2013.

574 Absence of ancient DNA in sub-fossil insect inclusions preserved in 'Anthropocene'

$575 \quad$ Colombian copal. PLoS ONE 8(9):e73150.

576 Poinar, H.N., Hofreiter, M., Spaulding, W.G., Martin, P.S., Stankiewicz, B.A., Bland, H., 577 Evershed, R.P., Possnert, G., Pääbo, S., 1998. Molecular coproscopy: dung and diet of 578 the extinct ground sloth Nothrotheriops shastensis. Science 281, 402-406.

579 Poinar, H., Kuch, M., McDonald, G., Martin, P., Pääbo, S., 2003. Nuclear gene sequences 580 from a late Pleistocene sloth coprolite. Curr. Biol. 13, 1150-1152.

581 R Development Core Team, 2009. R: A Language and Environment for Statistical 582 Computing. R Foundation for Statistical Computing, Vienna. 
583 Rao, S.A., Mengesha, M.H., Sharma, D., 1985. Collection and evaluation of pearl millet

584 (Pennisetum americanum) germplasm from Ghana. Econ. Bot. 39, 25-38.

585 Rattray, R.S., 1932. Tribes of the Ashanti Hinterland. Clarendon Press, Oxford.

586 Reed, F.A., Kontanis, E.J., Kennedy, K.A.R., Aquadro, C.F., 2003. Ancient DNA prospects

587 from Sri Lankan highland dry caves support an emerging global pattern. Am. J. Phys.

$588 \quad$ Anthropol. 121, 112-116.

589 Schroeder, H., Ávila-Arcos, M.C., Malaspinas, A.S., Poznik, G.D., Sandoval-Velasco, M.,

590 Carpenter, M.L., Moreno-Mayar, J.V., Sikora, M., Johnson, P.L., Allentoft, M.E.,

591 Samaniego, J.A., Haviser, J.B., Dee, M.W., Stafford, T.W., Salas, A., Orlando, L.,

592 Willerslev, E., Bustamante, C.D., Gilbert, M.T., 2015. Genome-wide ancestry of $17^{\text {th }}$ -

593 century enslaved Africans from the Caribbean. Proc. Natl. Acad. Sci. U.S.A. 112, 3669-

5943673.

595 Shale, K., Mukamugema, J., Lues, R.J., Venter, P., De Smidt, O., 2012. Microbiota

596 associated with commercially produced traditional banana beer in Rwanda. Sci. Res.

$597 \quad$ Essays 7, 4037-4046.

598 Smith, C.I., Chamberlain, A.T., Riley, M.S., Stringer, C., Collins, M.J., 2003. The thermal 599 history of human fossils and the likelihood of successful DNA amplification. J. Hum. Evol. $600 \quad 45,203-217$.

601 Speirs, A.K., McConnachie, G., Lowe, A.J., 2009. Chloroplast DNA from 16th century 602 waterlogged oak in a marine environment: initial steps in sourcing the Mary Rose timbers, 603 in: Haslam ,M., Robertson, G., Crowther, A., Nugent, S., Kirkwood, L. (Eds.), 604 Archaeological Science Under a Microscope (Terra Australis 30), ANU Press, Canberra, 605 pp. $175-189$.

606 Stahl, A.B., 2004. Political economic mosaics: archaeology of the last two millennia in 607 tropical Sub-Saharan Africa. Ann. Rev. Anthropol. 33, 145-172. 
608 Stover, R.H., Simmonds, N.W., 1995. Bananas (Tropical Agriculture Series), third ed. Wiley609 Blackwell, Chichester.

610 Tezenas Du Montcel, H., De Langhe, E,, Swennen, R., 1983. Essai de classification des 611 bananiers plantains (AAB). Fruits $38,461-474$.

612 van Andel, T., Myren, B., van Onselen, S., 2012. Ghana's herbal market. J.

613 Ethnopharmacol. 140, 368-378.

614 Wicklow, D.T., 1973. Microfungal populations in surface soils of manipulated prairie stands. 615 Ecology 54, 1302-1310.

616 Willerslev, E., Cooper, A., 2005. Ancient DNA. Proc. Biol. Sci. 272, 3-16.

617 Yellen, J.E., 1998. Barbed bone points: tradition and continuity in Saharan and Sub-Saharan 618 Africa. Afr. Archaeol. Rev. 15, 173-198.

619 
620 Figure legends

621

622 Fig. 1. Location of Yikpabongo village in the Builsa district, Northern Ghana.

623

624 Fig. 2. Terracotta items from which samples were taken. Scale bars in $\mathrm{cm}$.

625

626 Supplementary Fig. 1. Alignment of cloned sequences from the TRNL PCR products of

627 samples YK07-2-B5.1A2 and YK11-H13H14-113114B to their closest BLAST matches,

628 members of the Musa genus and Ensete (Musella) genera. The alignment includes YK07-2-

629 B5.1B2 clone 9, which has some similarity with Musa/Ensete but which we do not consider

630 to be a convincing match to these genera.

631

632 Supplementary Fig. 2. Alignment of sequences from the TRNL PCR products of samples

633 YK07-2-A4-1C1 and YK11-H13H14-113114B giving BLAST matches to Order Pinales.

634 Matches primarily belong to the Pinus genus with the exception of Araucacia araucana (not

635 shown). The twelve Pinales clones generated from samples YK07-2-A4-1C1 (five clones)

636 and YK11-H13H14-113114B (seven clones) share a single identical sequence.

637

638 Supplementary Fig. 3. Alignment of (A) RBCL sequences from the 'seated female figure' 639 YK10-D11-3, and (B) TRNL sequence from YK10-D11-3 with their closest BLAST matches 640 from the Poaceae family. The same TRNL sequence was obtained from nine separate 641 clones.

642 
643 Supplementary Fig. 4. Alignment of the most frequently represented 454 sequences from

644 the mouth cavity of the 'horse and rider' YK08-AB9-L7, with their closest BLAST matches in 645 genus Coniochaeta. 
Table 1

Terracotta items (Insoll et al., 2013) and samples that were taken.

\begin{tabular}{|c|c|c|c|}
\hline Accession number* & Item description & Sample & Sample description \\
\hline YK07-2-85-1 & circular disc/horn stopper & $\begin{array}{l}\text { YK07-2-85-1A } \\
\text { YK07-2-85-1B }\end{array}$ & $\begin{array}{l}\text { smooth side } \\
\text { patterned side }\end{array}$ \\
\hline YK07-2-A4-1 & large conical figure & $\begin{array}{l}\text { YK07-2-A4-1A } \\
\text { YK07-2-A4-1C1 } \\
\text { YK07-2-A4-1C2 }\end{array}$ & $\begin{array}{l}\text { exterior (black residue) } \\
\text { exterior (no residue) } \\
\text { exterior (no residue) }\end{array}$ \\
\hline YK07-2-A8-1 & anencephalic head & $\begin{array}{l}\text { YK07-2-A8-1A } \\
\text { YK07-2-A8-1B } \\
\text { YK07-2-A8-1C } \\
\text { YK07-2-A8-1S }\end{array}$ & $\begin{array}{c}\text { interior (mouth) } \\
\text { interior (mouth) } \\
\text { exterior } \\
\text { cavity soil (mouth) } 0.32 \mathrm{~g}\end{array}$ \\
\hline YK07-2-B5-1 & circular disc/horn stopper & $\begin{array}{l}\text { YK07-2-B5-1A } \\
\text { YK07-2-B5-1B }\end{array}$ & $\begin{array}{l}\text { rough side } \\
\text { smooth side }\end{array}$ \\
\hline YK07-2-B5.1 & large head (Mohican head) & $\begin{array}{l}\text { YK07-2-B5.1A2 } \\
\text { YK07-2-B5.1B2 } \\
\text { YK07-2-B5.1S }\end{array}$ & $\begin{array}{c}\text { interior (mouth) } \\
\text { exterior (left of mouth) } \\
\text { cavity soil (mouth) } 0.09 \mathrm{~g}\end{array}$ \\
\hline YK07-2-C3-1 & undecorated cone with skirt & $\begin{array}{l}\text { YK07-2-C3-1A } \\
\text { YK07-2-C3-1B } \\
\text { YK07-2-C3-1A2 } \\
\text { YK07-2-C3-1B2 } \\
\text { YK07-2-C3-1S }\end{array}$ & $\begin{array}{c}\text { interior } \\
\text { exterior } \\
\text { interior } \\
\text { exterior } \\
\text { cavity soil } 0.08 \mathrm{~g}\end{array}$ \\
\hline
\end{tabular}


YK07-2-C4-L2

YK07-2-O2-1

YK08-AB9-L7

YK08-A9B9-L7

human head wearing cap

YK10-D11-3

YK10-011-3

stylised androgynous human head

YK11-H13H14-113114 combined human and animal head
YK07-2-C4-L2A YK07-2-C4-L2B

YK07-2-O2-1A YK07-2-O2-1B YK07-2-O2-1C YK07-2-O2-1SA YK07-2-O2-1SB

YK08-AB9-L7A YK08-AB9-L7B YK08-AB9-L7C YK08-AB9-L7S

YK08-A9B9-L7A YK08-A9B9-L7B YK08-A9B9-L7S

YK10-D11-3A YK10-D11-3B

YK10-D11-3C

YK10-D11-3D

YK10-D11-3H

YK10-D11-3I

YK10-D11-3SA

\section{YK10-011-3E \\ YK10-011-3F \\ YK10-011-3SB}

YK11-H13H14-113114A YK11-H13H14-113114B YK11-H13H14-113114C rough side smooth side

exterior

interior (large mouth)

interior (small mouth)

cavity soil (large mouth) $0.29 \mathrm{~g}$ cavity soil (small mouth) $0.1 \mathrm{~g}$

interior (left mouth cavity)

interior (left mouth cavity) exterior

cavity soil (mouth) $0.036 \mathrm{~g}$

interior (mouth) exterior

cavity soil (mouth) $0.058 \mathrm{~g}$

interior (top of head)

interior (top of head)

exterior (right face)

exterior (top of head)

interior (left nostril)

interior (right nostril)

cavity soil $0.095 \mathrm{~g}$

interior (ear hole)

exterior (right face) cavity soil (ear) $0.120 \mathrm{~g}$

interior (mouth) interior (right nostril) exterior (right face) 
* Mound YK07 was excavated in 2007 (all items with names starting YK07) then again in 2008 (all item names starting with YK08).

Mound YK10-3/YK11 was excavated in 2010 (items starting YK10) and 2011 (items starting YK11). YK07-2-A8-1 is also listed under accession number YK07-2-D5-1 (Insoll et al., 2013). 


\section{Table 2}

Thermal age estimates for the terracotta items.

\begin{tabular}{|c|c|c|c|c|c|c|}
\hline $\begin{array}{l}\text { Excavation } \\
\text { series }\end{array}$ & $\begin{array}{c}\text { Excavation } \\
\text { year }\end{array}$ & Mound & $\begin{array}{l}\text { Effective burial } \\
\text { temperature }\left({ }^{\circ} \mathrm{C}\right)^{*}\end{array}$ & $\begin{array}{l}\text { Estimated date } \\
\qquad(\mathrm{BP})\end{array}$ & $\begin{array}{l}\text { Thermal age estimate } \\
\left(10^{\circ} \mathrm{C} \text { thermal years }\right)^{*}\end{array}$ & $\lambda^{\dagger}$ \\
\hline YK07 & 2007 & \multirow{2}{*}{ YK07 } & \multirow{2}{*}{$28.4-28.7$} & \multirow{2}{*}{$979-1317 \pm 39$} & $18640-28929$ & \multirow{2}{*}{$0.056-0.087$} \\
\hline YK08 & 2008 & & & & $18567-29044$ & \\
\hline YK10 & 2010 & \multirow{2}{*}{ YK10-3/YK11 } & \multirow{2}{*}{$28.4-28.7$} & \multirow{2}{*}{$780-940 \pm 40$} & 22559-28207 & \multirow{2}{*}{$0.067-0.085$} \\
\hline YK11 & 2011 & & & & $22583-28239$ & \\
\hline
\end{tabular}

* Effective burial temperatures and thermal ages were estimated with JRA 1: PrediCtoR (available from http://thermal-age.eu)

based on excavation depths of $10-20 \mathrm{~cm}$, silt loam soil type, site elevation of $735 \mathrm{~m}$, and water saturation of $15 \%$, storage at $16 \pm$ $5^{\circ} \mathrm{C}$ post-excavation, and sample analysis in 2014 .

${ }^{\dagger}$ Estimated proportion of nucleotide bases damaged by depurination, based on the degradation pattern of bone aDNA, corresponding to mean fragment lengths of 13-19 bp for items from mound YK07, and 13-16 bp for the items from YK10-3/YK11. 


\section{Table 3}

Details of PCRs.

\begin{tabular}{|c|c|c|c|c|c|}
\hline PCR & Primer sequences* & $\begin{array}{l}\text { Product size } \\
\text { (bp) }\end{array}$ & Target & Reference & $\begin{array}{c}\text { Annealing } \\
\text { temperature }\left({ }^{\circ} \mathrm{C}\right)\end{array}$ \\
\hline ATPC & $\begin{array}{c}\text { F: CCGCCCTCGTCTTCTCAT } \\
\text { R: ATCGGGCAATGGGTGGCGGA }\end{array}$ & 133 & $\begin{array}{l}\text { Pearl millet ATPase } \\
\text { gene }\end{array}$ & This study & 58 \\
\hline CYTB & $\begin{array}{l}\text { F: ATAGACAAAATCCCATTCCA } \\
\text { R: TAGTTGTCAGGGTCTCCTAG }\end{array}$ & 125 & $\begin{array}{l}\text { Mammalian cytochrome } \\
\text { b gene }\end{array}$ & $\begin{array}{l}\text { Irwin et al. } \\
\quad(1991)\end{array}$ & 54 \\
\hline HVR1 & $\begin{array}{l}\text { F: ACAGCAATCAACCCTCAACTATCA } \\
\text { R: TGTGCTATGTACGGTAAATGGCTT }\end{array}$ & 131 & $\begin{array}{l}\text { Human mitochondrial } \\
\text { HVR1 }\end{array}$ & $\begin{array}{l}\text { Bouwman et al. } \\
\qquad(2008)\end{array}$ & 58 \\
\hline RBCL & $\begin{array}{l}\text { F: GGCAGCATTCCGAGTAACTCCTC } \\
\text { R: CGTCCTTTGTAACGATCAAG }\end{array}$ & 137 & Plant RuBisCO gene & $\begin{array}{l}\text { Poinar et al. } \\
\quad(1998)\end{array}$ & 58 \\
\hline RBSP & $\begin{array}{l}\text { F: AGAAGAAAGAGAAGAAGCACG } \\
\text { R: GGACAGCTCGTATTATAACCTGC }\end{array}$ & 143 & $\begin{array}{l}\text { Maize ribosomal protein } \\
\text { gene }\end{array}$ & $\begin{array}{l}\text { Gyulai et al. } \\
\qquad(2007)\end{array}$ & 60 \\
\hline RDNA & $\begin{array}{l}\text { F: CAGCGGGTACTCCTACCTGA } \\
\text { R: GAGAGGTTTCTCTGCGTGCT }\end{array}$ & 136 & $\begin{array}{l}\text { Ascomycete ribosomal } \\
\text { DNA }\end{array}$ & This study & 58 \\
\hline TRNL & $\begin{array}{l}\text { F: GGCAATCCTGAGCCAAATC } \\
\text { R: GAGTCTCTGCACCTATCCT }\end{array}$ & $80-85$ & $\begin{array}{l}\text { Plant chloroplast trnL } \\
\text { gene }\end{array}$ & This study & 58 \\
\hline
\end{tabular}

${ }^{*} \mathrm{~F}$, forward primer; $\mathrm{R}$, reverse primer 


\section{Table 4}

Results of PCRs with the RBCL and TRNL primer pairs.

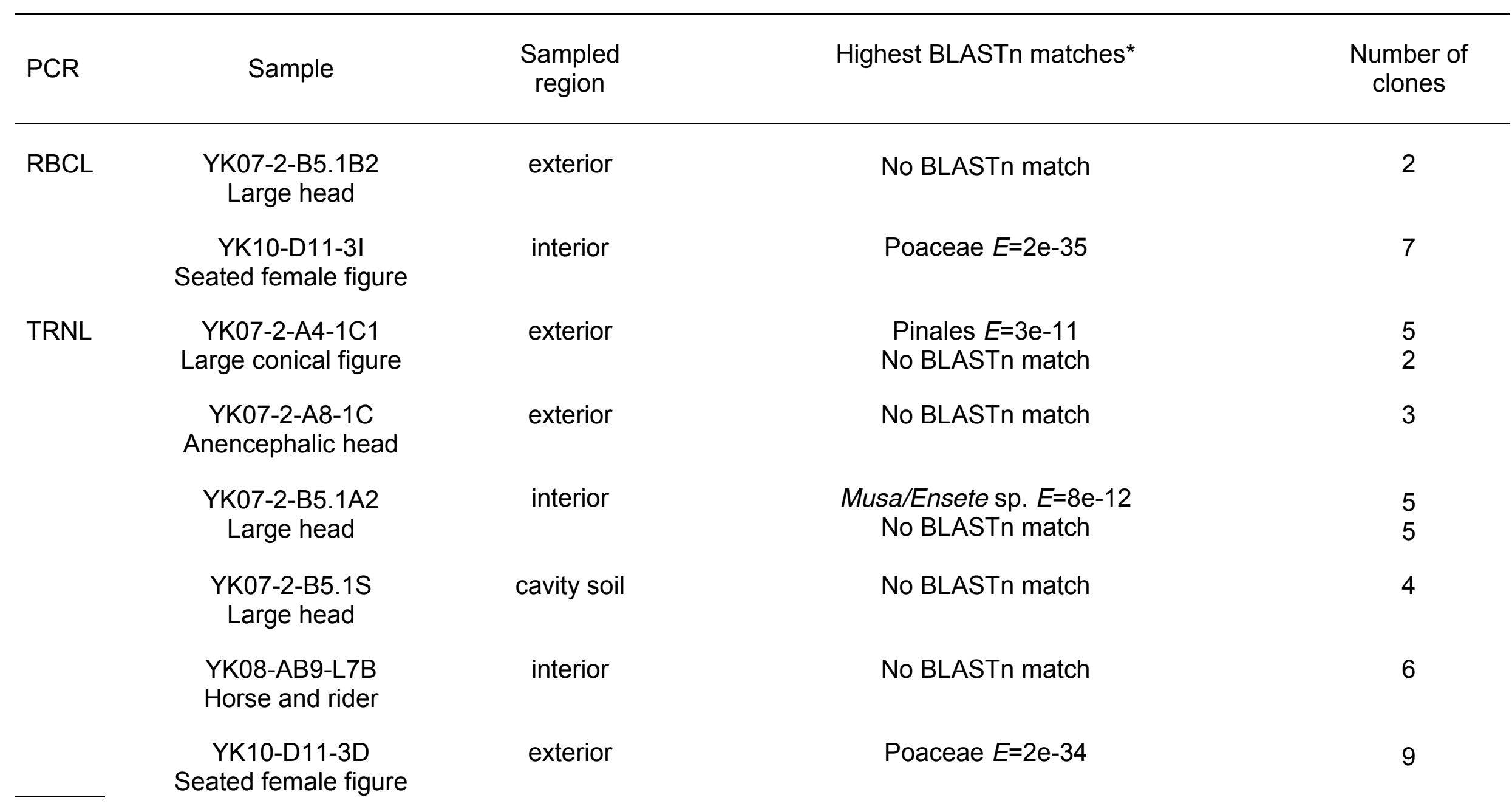


YK11-H13H14-113114B

Combined human and animal head interior

Pinales $E=8 \mathrm{e}-11$

Musa/Ensete sp. $E=4 \mathrm{e}-29$

BLASTn match

* 'No BLASTn match' denotes that BLASTn analysis only retrieved database entries with low $E$ values and/or high numbers of mismatches. These results include one additional TRNL sequence from YK07-2-B5.1B2 for which the highest BLASTn match was Musa/Ensete but with seven differences in a 42 bp sequence (shown in Fig. S1). 
Click here to download high resolution image

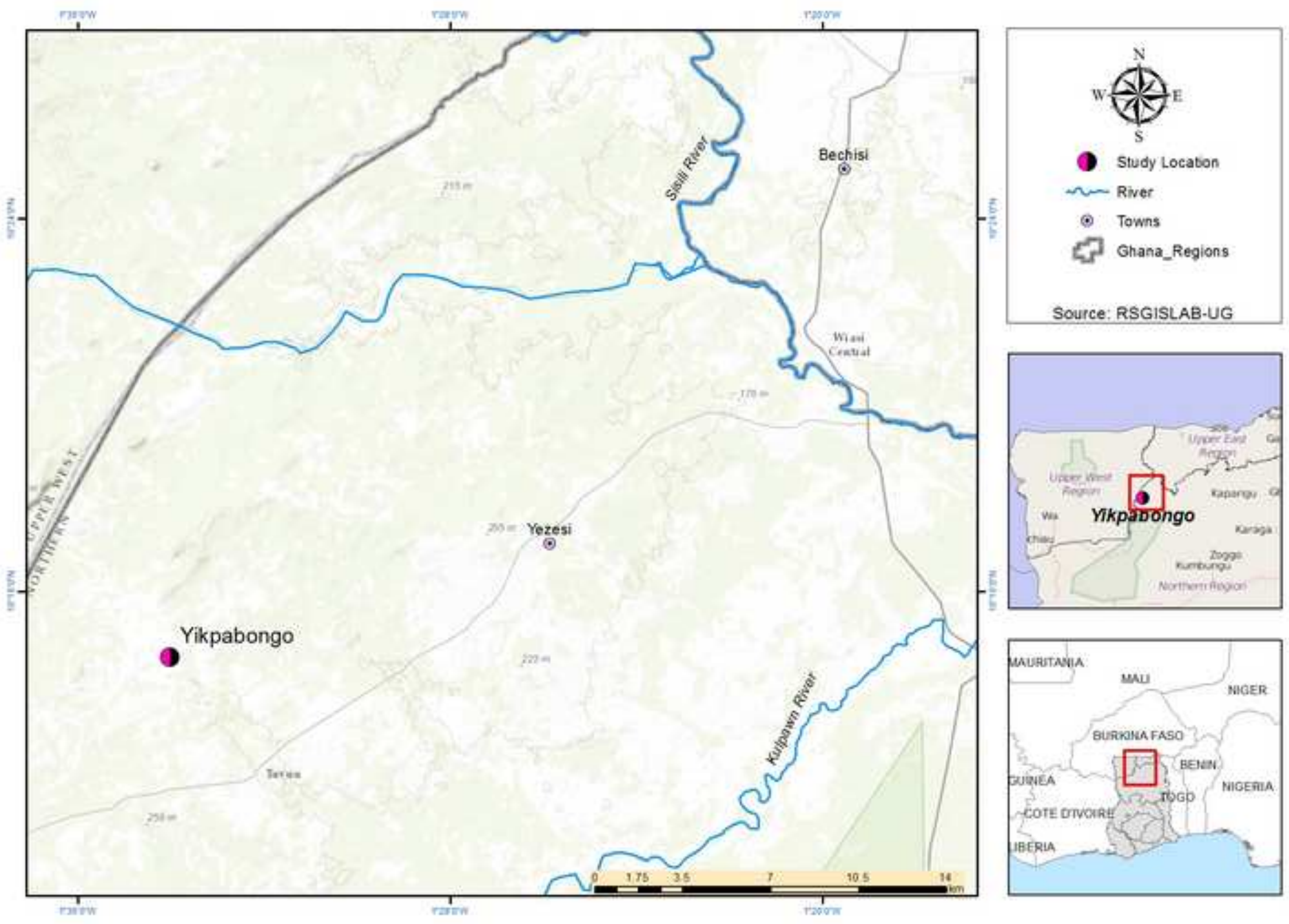


Figure 1
Click here to download high resolution image

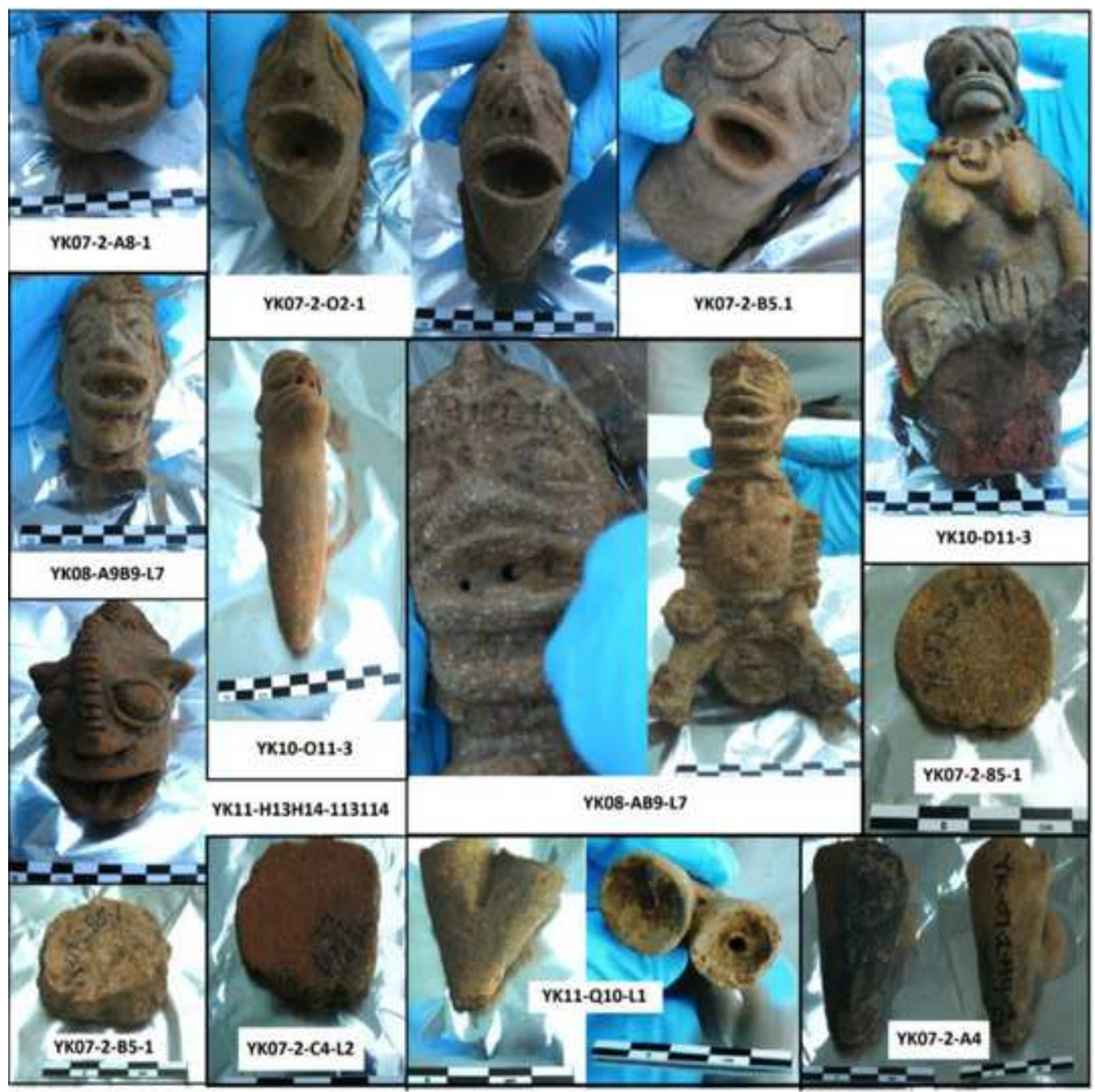

